Amsterdam Expeditions to the West Indian Islands, Report 23*)

\title{
BOGIDIELLA (B.) NEOTROPICA RUFFO, 1952 (CRUSTACEA, AMPHIPODA) REDISCOVERED IN VENEZUELA
}

\author{
by \\ DIRK PLATVOET \\ Institute of Taxonomic Zoology, University of Amsterdam, P.O. Box 20125, 1000 HC Amsterdam, \\ The Netherlands
}

\section{SUMMARY}

Bogidiella neotropica was described by Ruffo in 1952 after a single specimen of unknown sex, from Amazonia (Brazil). Both sexes have been found recently in the Guarico district, Venezuela. From the absence of secondary sexual differences in the male appendages it is clear that the species belongs to the subgenus Bogidiella s. str. The Venezuelan specimens are redescribed and illustrated.

\section{RÉSUMÉ}

Bogidiella neotropica a été décrite par Ruffo en 1952 d'après un exemplaire unique, de sexe inconnu, provenant d'Amazonie (Brésil). Récemment, plusieurs exemplaires (des deux sexes) ont été capturés dans le district de Guarico, au Vénézuéla. L'absence de différences sexuelles secondaires dans les appendices du mâle montre clairement que l'espèce appartient au sous-genre Bogidiella s. str. Les exemplaires du Vénézuéla ont permis de donner une redescription illustrée de l'espèce.

\section{INTRODUCTION}

During one of the Amsterdam Expeditions to the West Indian Islands, in the beginning of 1982, J. H. Stock c.s. took samples in wells around Calabozo, near the river Guarico, part of the drainage of the Orinoco. In seven samples bogidiellid amphipods were found which appear to belong to the subgenus Bogidiella s. str. and which show a remarkable resemblance to Bogidiella neotropica Ruffo, 1952.

As there is a distance of two thousand kilometres between the type-locality of $B$. neotropica in Amazonia (Brazil) and the Venezuelan sampling localities, and since Ruffo based his description of $B$. neotropica on one

*) Report 22 is published in the same issue of this journal. specimen only, of which he was unable to determine the sex, it is considered useful to give a description of the Venezuelan material.

\section{DESCRIPTIVE PART}

Bogidiella (B.) neotropica Ruffo, 1952

Material examined. - VENEZUELA, district of Guarico:

- Sta. 82-548, 9-III-1982, well near Orituco, between Biological Station Mantecal ("Estacion Biologica de la Sociedad Venezolana de Ciencias") and Paso el Cabello $\left(08^{\circ} 46^{\prime} 26^{\prime \prime} \mathrm{N} \quad 67^{\circ} 18^{\prime} 22^{\prime \prime} \mathrm{W}\right): 1$ specimen, Zoölogisch Museum Amsterdam coll. no. ZMA Amph. 107.571A.

- Sta. 82-549, 9-III-1982, well near Moricial Redondo, between Biological Station Mantecal and Paso el Cabello $\left(09^{\circ} 11^{\prime} 37^{\prime \prime} \mathrm{N} 67^{\circ} 00^{\prime} 32^{\prime \prime} \mathrm{W}\right)$ : 1 specimen, $\sigma^{\circ}$ (see description), ZMA Amph. 107.571B.

- Sta. 82-550, 9-III-1982, $200 \mathrm{~m}$ from above-mentioned locality: 2 specimens, ZMA Amph. 107.571C.

- Sta. 82-552, 9-III-1982, well along road from Biological Station Mantecal to Paso el Cabello $\left(08^{\circ} 39^{\prime} 09^{\prime \prime} \mathrm{N} 67^{\circ} 16^{\prime} 44^{\prime \prime} \mathrm{W}\right): 1 \%, 6$ specimens of undetermined sex, ZMA Amph. 107.573.

- Sta. 82-558, 10-III-1982, well at Calabozo $\left(08^{\circ} 55^{\prime} 17^{\prime \prime} \mathrm{N} 67^{\circ} 27^{\prime} 00^{\prime \prime} \mathrm{W}\right): 2$ specimens, ZMA Amph. 107.571D.

- Sta. 82-564, 10-III-1982, well at Calabozo $\left(08^{\circ} 54^{\prime} 00^{\prime \prime} \mathrm{N} 67^{\circ} 25^{\prime} 23^{\prime \prime} \mathrm{W}\right): 5$ specimens, ZMA Amph. 107.571E.

- Sta. 82-565, 10-III-1982, other well at same locality: 2 specimens, ZMA Amph. 107.571F.

- Sta. 82-566, 10-III-1982, well at Calabozo $\left(08^{\circ} 55^{\prime} 53^{\prime \prime} \mathrm{N} 67^{\circ} 25^{\prime} 23^{\prime \prime} \mathrm{W}\right)$ : 1 specimen, ZMA Amph. 107.571G.

Description. - A relatively large, blind and unpigmented species (body length without antennae and third uropod $6 \mathrm{~mm}$ ) (fig. 1A). 

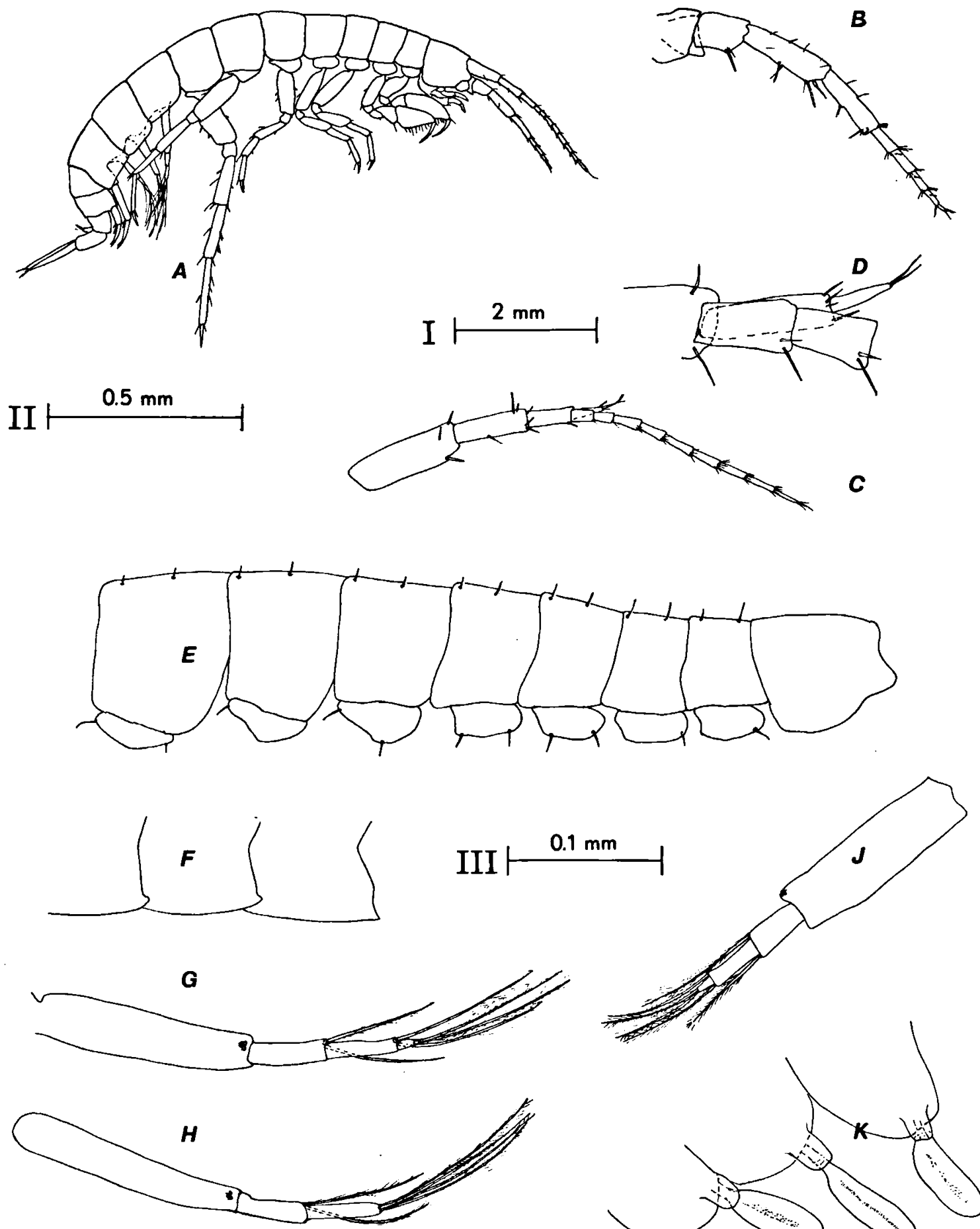

C

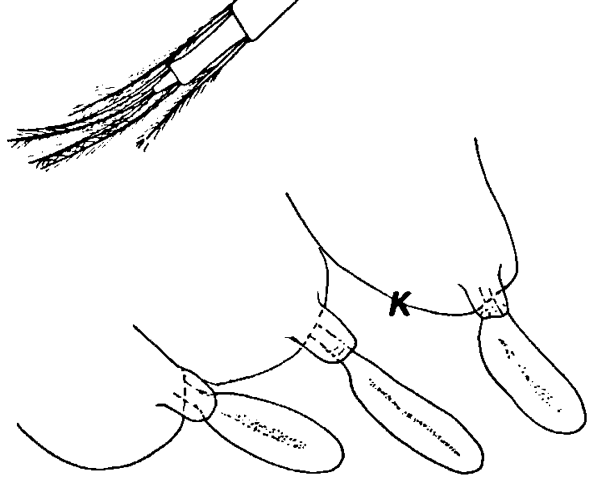

Fig. 1. Bogidiella (B.) neotropica Ruffo, 1952, o from Sta. 82-549: A, habitus (scale I); B, second antenna (II); C, first antenna (II); D, accessory flagellum (III); E, coxal plates (II); F, epimeral plates (II); G, first pleopod (IV); H, second pleopod (IV); J, third pleopod (IV); K, coxal gills on pereionites 4, 5 and 6 (IV). 
Male: Coxal plates not overlapping, wider than long with one or two setae on distal margin (fig. 1E). Small posteroventral projection on epimeral plates, all three unarmed (fig. 1F). Dorsum smooth with 2-4 dorsolateral setae. Coxal gills on pereionites 4,5 and 6 (fig. 1K).

First antenna somewhat longer than second antenna, about one third of the body length. Peduncle shorter than flagellum, first segment about as long as second and third together. Flagellum 9-segmented with short setae, without aesthetasks. Accessory flagellum 2-segmented (figs. 1C and 1D). Second antenna with short, 5-segmented flagellum without calceoli and with a short gland cone (fig. 1B).

Mandible with strong pars molaris, pars incisiva with three well-developed teeth. Three feathered setae implanted between pars molaris and lacinia mobilis. Lacinia mobilis with 5 teeth (fig. 3D).

Maxilla 1: inner lobe with two elements, outer lobe with 6 spines, each armed with one or two denticles. Palp 2-segmented, second palp segment with two terminal setae (fig. $3 \mathrm{E}$ ).

Maxilla 2: 5 setae on each lobe (fig. 3F).

Maxilliped: inner and outer lobes small, inner lobe with one large spine and three setae, outer lobe with two spines and one seta. Palp 3-segmented with long, slender dactylus (fig. $3 \mathrm{G})$.

First gnathopod: basis short with two small distal setae, merus with setules on posterior margin, carpus with strong, pointed posterior lobe armed with 2 setae and small setules. Propodus with three spines on very oblique palm. Dactylus with two small excavations on inner margin with setae inserted within (figs. 2A and 2B).

Second gnathopod more slender than first, basis with two small distal setae. Merus without setules. Carpus with a weak, rounded posterior lobe. Propodus of second smaller than that of first gnathopod. Palmar margin with one large and two smaller spines (figs. 2C and 2D).

Third and fourth pereiopod slender, with few spines and setae (figs. $2 \mathrm{E}$ and $2 \mathrm{~F}$ ).

Fifth and sixth pereiopod short, almost without setae (figs. 3A and $3 B$ ).
Seventh pereiopod very long, almost twice the length of the fifth, with long spines and a few short setae (fig. 3C).

Pleopods without endopodite and without modifications for sperm transfer, basipodite with two retinacula. Exopodite 3-segmented, each segment bearing two feathered setae (figs. $1 \mathrm{G}, 1 \mathrm{H}$ and $1 \mathrm{~J})$.

Uropods 1 and 2 as illustrated (figs. $2 \mathrm{G}$ and $2 \mathrm{H})$.

Uropod 3 with two long rami, subequal in length and both monomerous (figs. $2 \mathrm{~J}$ and $2 \mathrm{~K}$ ).

Telson with shallow emargination, armed with 4 spines and two setae (fig. 2L). The spines have a setule near their apex.

Female: The only specimen which can be recognized with certainty as a female lacks many appendages. There are six eggs on the ventral side of pereionites 2-7. These eggs are still undeveloped and seem to be incorporated in the body instead of being carried in a marsupium.

Though many appendages are missing, secondary sexual differences seem to be insignificant, apart from the flagellum of antenna 1 , which is 7 -segmented in the female.

\section{DISCUSSION}

The Venezuelan material agrees quite well with the holotype of $B$. neotropica. The latter could be re-examined thanks to the kind assistance of Dr. S. Ruffo, Verona. Although the distance between the type-locality and the present records amounts to some $2000 \mathrm{~km}$, it is a wellknown fact that the drainage systems of the Orinoco and Amazon rivers are interconnected, making an exchange of genetic material plausible. Both the Brazilian and Venezuelan stations are located within the neotropical belt.

The morphology of the hitherto unknown male makes it clear that $B$. neotropica belongs to the subgenus Bogidiella s. str., characterized by the absence of secondary sexual modifications in the male pleopods and uropods (cf. Stock, 1981). 

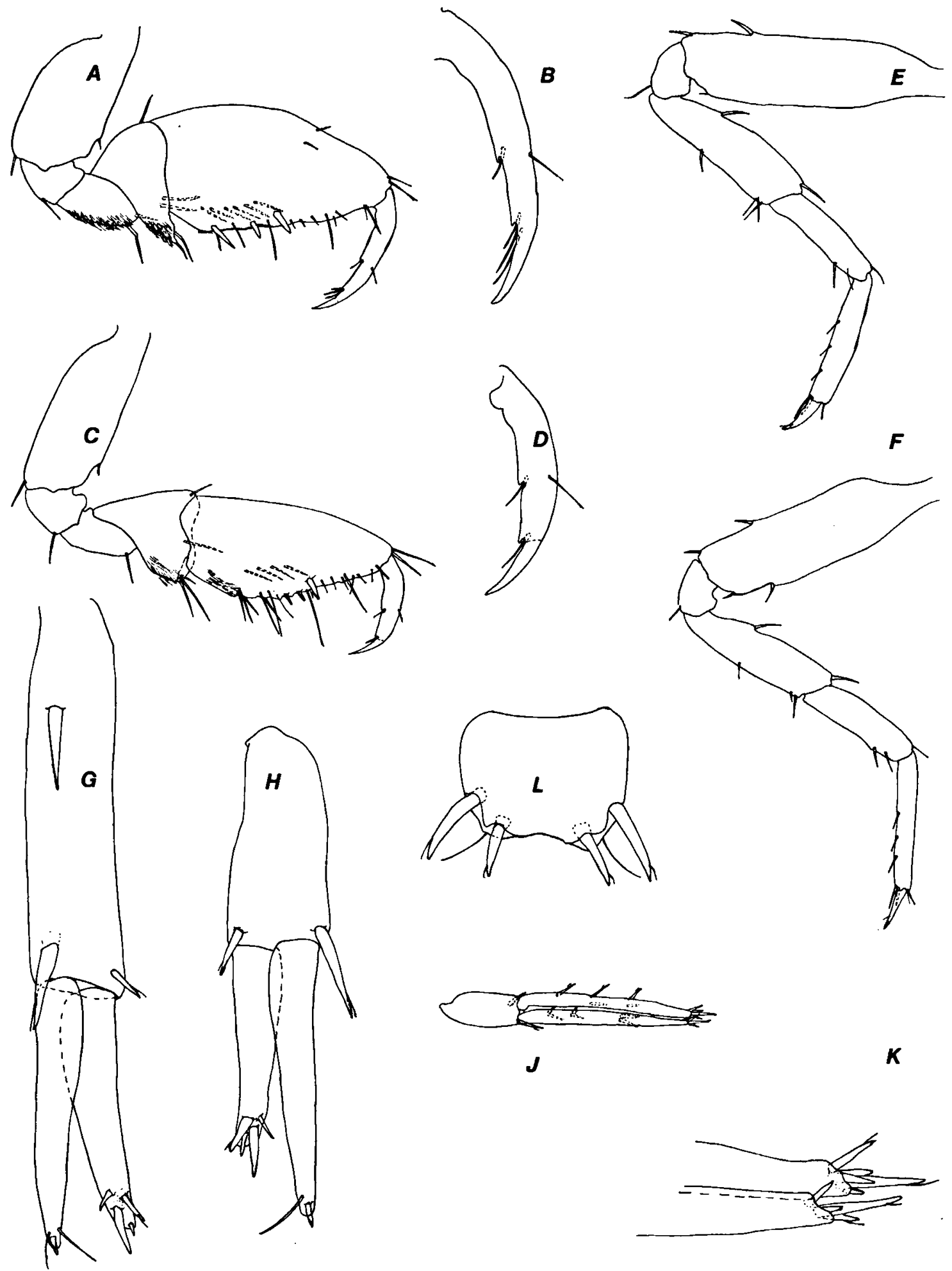

$\boldsymbol{K}$

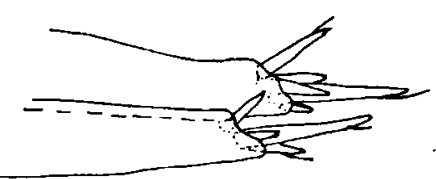

Fig. 2. Bogidiella (B.) neotropica Ruffo, 1952, ơ from Sta. 82-549: A, first gnathopod (scale IV); B, dactylus P1 (III); C, second gnathopod (IV); D, dactylus P2 (III); E, third pereiopod (IV); F, fourth pereiopod (IV); G, first uropod (III); H, second uropod (III); J, third uropod (II); K, detail of third uropod; L, telson (III). 

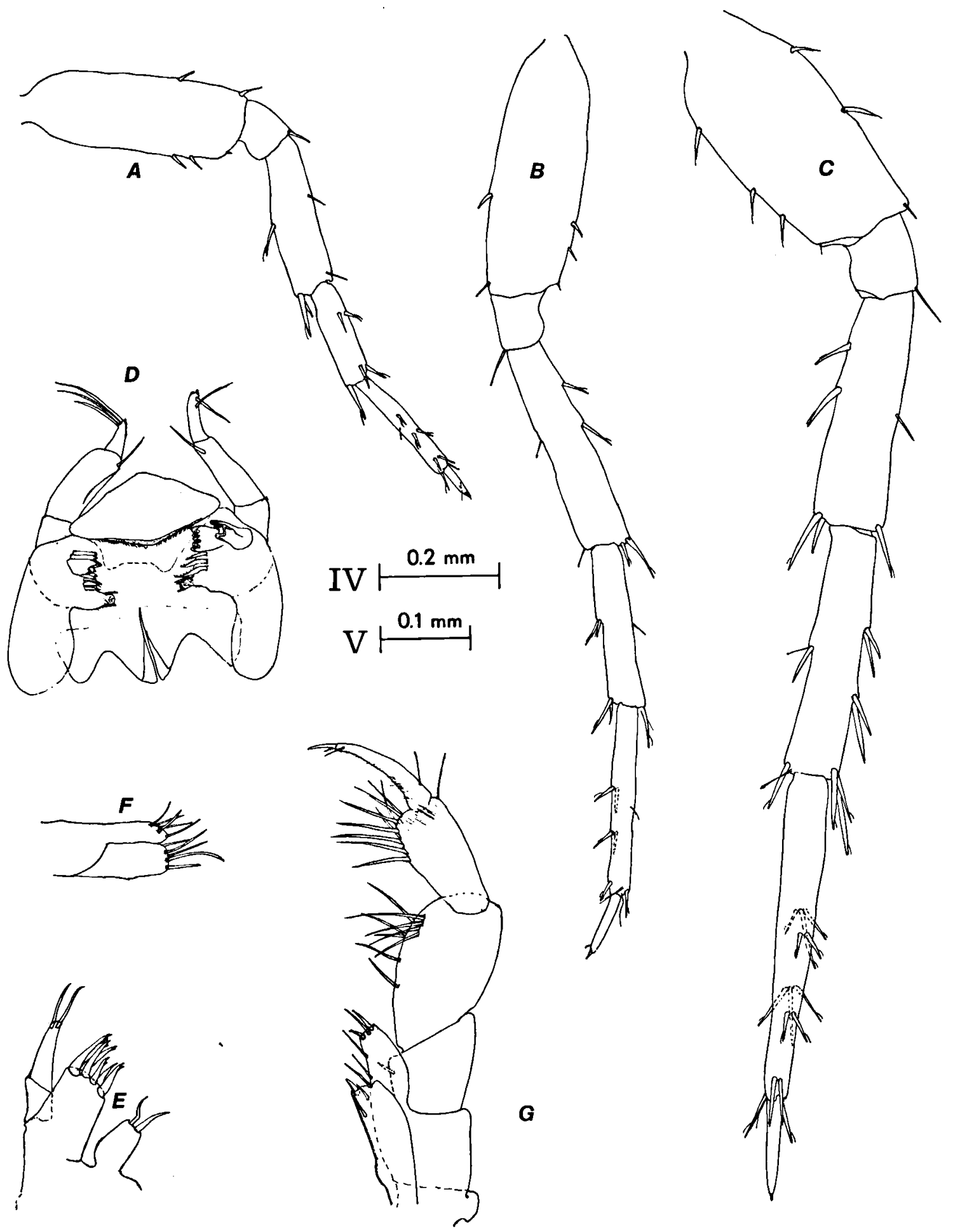

Fig. 3. Bogidiella (B.) neotropica Ruffo, 1952, o from Sta. 82-549: A, fifth pereiopod (scale IV); B, sixth pereiopod (IV); C, seventh pereiopod (IV); D, mandibles with palps, labrum and labium (V); E, first maxilla (III); F, second maxilla (III); G, maxilliped (III). 


\section{ACKNOWLEDGEMENTS}

The author is indebted to Prof. Dr. J. H. Stock for his good advice, and to Prof. Dr. Sandro Ruffo who kindly provided the material of $B$. neotropica. The fieldwork of the Amsterdam West Indian Island Expeditions has been supported by grants from the Netherlands Foundation for the Advancement of Tropical Research (WOTRO) (The Hague), the Beijerinck-Popping Fonds (Amsterdam), the Treub Maatschappij (Utrecht), and the Amsterdamse Universiteits Vereniging (Amsterdam).

\section{REFERENCES}

Sтоск, J. H., 1981. Amsterdam Expeditions to the West Indian Islands, Report 14. The taxonomy and zoogeography of the family Bogidiellidae (Crustacea, Amphipoda), with emphasis on the West Indian taxa. Bijdr. Dierk., 51 (2): 345-374.

Rufro, S., 1952. Bogidiella neotropica n.sp., nuovo Anfipodo dell'Amazonia. Schweiz. Z. Hydrol., 14: 129-134.

Received: 11 November 1982 